\title{
Adenoviral Gene Transfer of a u-PA Receptor-binding Plasmin Inhibitor and Green Fluorescent Protein: Inhibition of Migration and Visualization of Expression
}

\author{
M. L. M. Lamfers, M. J. Wijnberg, J. M. Grimbergen, L. G. M. Huisman, M. C. Aalders, \\ F. N. B. Cohen, J. H. Verheijen, V. W. M. van Hinsbergh, P. H. A. Quax
}

From the Gaubius Laboratory TNO-PG, Leiden, The Netherlands

\section{Key words}

SMC migration, plasminogen activators, plasmin, gene therapy, green fluorescent protein

\section{Summary}

Smooth muscle cell migration plays a role in the development of intimal hyperplasia. Given the established role of the plasminogen activation system in cell migration, an approach to therapy is to overexpress an inhibitor of plasmin. Therefore, an adenoviral vector was constructed encoding the hybrid protein ATF.BPTI, which contains the active domain of bovine pancreas trypsin inhibitor (BPTI), fused to ATF, the amino terminal fragment or receptor-binding domain of u-PA. Adenoviral vectors expressing ATF and BPTI individually were also constructed, and a fourth vector was constructed encoding ATF.BPTI linked by an internal ribosomal entry site to Green Fluorescent Protein (ABIG). Both the expression and functionality of the recombinant proteins were established in human vascular smooth muscle cells. Adenoviral gene transfer of ATF.BPTI inhibited SMC migration more efficiently than the expression of ATF or BPTI individually. Expression of ABIG resulted in the co-expression of ATF.BPTI and Green Fluorescent Protein, thereby providing a tool to monitor transfection efficiency and the behavior of the transfected cells.

\section{Introduction}

Migration and proliferation of vascular smooth muscle cells (SMC) play a fundamental role in the development of intimal hyperplasia. Migration of cells within tissues requires controlled proteolytic degradation of the extracellular matrix (ECM) that encages them. Several proteolytic enzyme systems play a role in these processes, including the plasminogen activation (PA) system. The serine protease plasmin can not only directly degrade components of the ECM but it can also act indirectly, enhancing pericellular proteolysis by activation of latent MMP's. The PA system is composed of the inactive proenzyme plasminogen that can be converted to its active derivative plasmin by urokinase-type plasminogen activator (u-PA) and tissue-type plasminogen activator (t-PA). U-PA plays a major role in local pericellular proteolysis, since it can bind to a specific cell surface receptor, the u-PA recep-

Correspondence to: Dr. P. H. A. Quax, Gaubius Laboratory TNO-PG, P.O. Box 2215, 2301 CE Leiden, The Netherlands - Tel.: 00-31-5181509; Fax: 0031-71-5181904; E-mail: PHA.Quax@pg.tno.nl tor (u-PAR) (1). A role for u-PA-mediated plasminogen activation in migration has been reviewed for a variety of cells in general and vascular SMCs and arterial remodeling in particular (5). In vitro studies have described the inhibitory effects on SMC migration of plasminogen activator inhibitor-1 (PAI-1), aprotinin, soluble u-PAR, and u-PA- and tPA antibodies. Furthermore, addition of exogenous u-PA, t-PA, or plasmin increases the migratory ability of SMC in vitro $(6,7)$. SMC isolated from u-PA or u-PAR deficient mice do not migrate in response to bFGF, while supplementation of cells from u-PA deficient animals with exogenous u-PA restores the migratory response (8). In vivo studies in balloon-injured rat carotid arteries have shown increases in u-PA, t-PA, PAI-1, u-PAR and overall plasmin activity at early times following arterial denudation. Treatment with the synthetic plasmin inhibitor tranexamic acid strongly reduced SMC migration in injured carotid arteries (10). Furthermore, Carmeliet et al. $(11,12)$ have shown that in $\mathrm{u}$ PA and plasminogen knock-out mice neointima formation and neointimal cell accumulation were strongly reduced.

U-PA consists of three distinct domains: the first region from the $\mathrm{N}$-terminus, referred to as the growth factor domain is followed by a second region referred to as the kringle domain, which together are known as the aminoterminal fragment of u-PA (ATF). The third region contains the serine protease domain (13-15). Binding of u-PA to the uPA receptor is mediated by its growth factor domain, thereby retaining the proteolytic activity through its carboxyterminal region. Binding to its receptor not only restricts the activity of u-PA to the direct cell environment, it also brings u-PA in close contact to plasminogen on its receptor, allowing the efficient activation of plasminogen to plasmin directly at the cell surface. Apart from its role in proteolysis, u-PA, or the receptor-binding non-proteolytic aminoterminal fragment, has been reported to have mitogenic effects on SMC (16) and various tumor cells $(17,18)$.

Given the established role for the PA system in cell migration and subsequent neointima formation, an approach to therapy is to overexpress an inhibitor of plasmin. Therefore, an adenoviral vector was constructed encoding the active domain of bovine pancreas trypsin inhibitor (BPTI), also known as aprotinin or Trasylol ${ }^{\circledR}$, a potent inhibitor of plasmin. Since cell-associated plasmin is protected from inhibition by its natural inhibitors $\alpha_{2}$-antiplasmin and $\alpha_{2}$-macroglobulin (19), an increased efficacy of BPTI is expected when it is brought to the cell surface. It has been reported that migrating cells overexpress the u-PA receptor (20), which is in close spatial proximity of the plasminogen receptor. Therefore, we have constructed a second adenoviral vector encoding the hybrid protein ATF.BPTI (21) in order to target BPTI to the cell surface $\mathrm{u}-\mathrm{PA}$ receptor. ATF, however, may achieve two additional effects, apart from its BPTI-anchoring function, upon binding to u-PAR: 1) an increase in inhibition of proteolysis by making the u-PA 


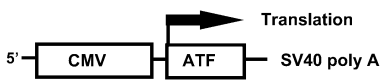

Ad.BPTI

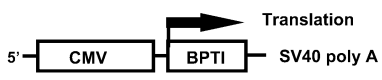

Ad.ATF.BPT

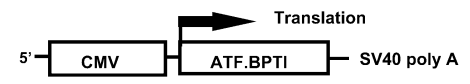

Ad.ABIG

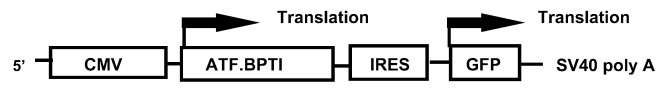

Fig. 1 Expression cassettes of the adenoviral vectors used in this study. The various protein coding sequences were placed under control of a CMV promoter. The introduction of the Internal Ribosome Entry Site (IRES) in the ABIG construct allows the translation of both ATF.BPTI and Green Fluorescent Protein (GFP) from the same mRNA

receptor inaccessible for (pro)u-PA and thus reducing plasminogen activation, 2) an increase in proliferation due to the reported mitogenic effects of ATF. To study the role of these effects on SMC migration a third adenoviral vector was constructed encoding ATF.

To identify the ATF.BPTI expressing cells a fourth adenoviral vector was constructed encoding both ATF.BPTI and Green Fluorescent Protein (GFP), which is isolated from the jellyfish Aequorea victoria, and is used widely as a non-invasive autofluorescent marker for gene expression $(22,23)$. It requires no other proteins, substrates, or cofactors to fluoresce and can be detected in viable cells or tissues, which is a major advantage over other reporter genes. Fusion of GFP to a gene of interest in an adenoviral vector would allow tracing of the transgeneproducing cell. However, fusion of the two proteins may alter the tertiary structure and subsequently the functionality of the proteins. Therefore, to coexpress the GFP gene with another gene of interest, the internal ribosome entry site (IRES) sequence of the encephalomyocarditis virus, was placed between the ATF.BPTI and the GFP gene, thereby creating Ad.ATF.BPTI.IRES.GFP (Ad.ABIG). This results in a construct with two independent translational units, allowing ATF.BPTI and GFP to be translated as two separate proteins from the same mRNA. Infection of cells with Ad.ABIG results in simultaneous expression of the secretable hybrid protein ATF.BPTI, and GFP, which remains intracellular. This provides us with a tool to monitor both transfection efficiency and behavior of the infected cells due to the visibility of GFP. This approach was used to demonstrate that ATF.BPTI-expressing SMC are inhibited in their migratory capacity. Furthermore, in this report we show that adenovirus-mediated overexpression of the cellsurface binding plasmin inhibitor ATF.BPTI is a potent therapeutic approach to inhibiting SMC migration in vitro. We demonstrate that inhibition of SMC migration by ATF.BPTI is more effective than by ATF or BPTI individually.

\section{Materials and Methods}

\section{Cell Culture}

Human saphenous vein smooth muscle cells (HSVSMC) were isolated from segments of saphenous vein obtained from patients undergoing coronary artery bypass grafting. Saphenous vein segments were kindly provided by the department of Thorax Surgery of the Leiden University Medical Center, Leiden, The Netherlands according to the guidelines of the local ethical committee. After mechanical removal of endothelial cells, the adventitia was carefully stripped from the media. The media was then cut into small fragments and SMC were isolated via the explant method (24). HSVSMC were cultured in Dulbecco's modified Eagle medium supplemented with $2 \mathrm{mmol} / \mathrm{L}$ glutamine (DMEM), $5 \%$ $(\mathrm{v} / \mathrm{v})$ heat inactivated $\left(30 \mathrm{~min}\right.$ at $56^{\circ} \mathrm{C}$ ) fetal calf serum (FCS), (Life Technologies, Paisley, Scotland), 5\% (v/v) heat-inactivated human serum, streptomycin $(100 \mu \mathrm{g} / \mathrm{ml})$ and penicillin $(100 \mathrm{U} / \mathrm{ml})$ (Biowhittaker, Verviers, Belgium) on gelatin (Merck, Darmstadt, Germany) coated dishes at $37^{\circ} \mathrm{C}$ in a humidified 5\% $\mathrm{CO}_{2} / 95 \%$ air (v/v) atmosphere. The medium was replaced every 2 to 3 days and subcultures were established by trypsin/EDTA treatment of confluent cultures. HSVSMC were used for experiments between passage 2-6.

HER-911 cells (kindly provided by Dr. F. Fallaux) (25), LB6 cells and CHO cells were cultured in DMEM supplemented with $10 \%$ (v/v) heat-inactivated FCS, streptomycin $(100 \mu \mathrm{g} / \mathrm{ml})$ and penicillin $(100 \mathrm{U} / \mathrm{ml})$.

\section{Construction of Adenoviral Vectors}

The main features of the vectors described below are illustrated in Fig. 1.

PCMVATF, pCMV.ATF.BPTI and pCMV.BPTI, the adenoviral shuttle vectors encoding ATF, the hybrid protein ATF.BPTI and BPTI were constructed by the following procedure. First, a vector containing the aminoterminal fragment of human u-PA, amino acids 1-138, further referred to as ATF, was constructed by deleting the DNA sequences encoding amino acids 139 to 401 from pCRII.u-PA, containing full length u-PA cDNA (26) using a polymerase chain reaction (PCR) with the oligonucleotides 5'CCCGGGCTTTTTTCCATCTGCGCAGTC3' and 5'AGGGTCACCAAGGAAGAGAATGGC3'. After amplification the DNA fragment was recircularised resulting in pCRII.ATF, encoding ATF and $11 \mathrm{C}$-terminal amino acid residues of $\mathrm{u}$-PA including the stop codon. A HindIII/EcoRV fragment of pcrII.ATF was cloned in the EcoRV/HindIII digested adenoviral shuttle vector pCMV.

A DNA fragment encoding amino acid residues 36-93 of bovine pancreatic trypsin inhibitor (BPTI) was amplified from bovine genomic DNA using the oligonucleotides 5'TCGCGACCTGACTTCTGCCTAGAGC3' covering nucleotides 2509 to 2533 of the BPTI gene and 5'GGTCACCCAGGGCCCAATATTACCACC3' covering nucleotides 2677 to 2704 of the BPTI gene as published (GENBANK, BTBPTIG). The amplified BPTI fragment was then cloned into a pCRII cloning vector (Invitrogen, Carlsbad, CA, USA). A NruI/ BsteII fragment of pCRII.BPTI was subsequently cloned into the SmaI/BsteII digested pCRII.ATF vector to form the pCRII.ATF.BPTI vector. A HindIII/ EcoRV fragment of pCRII.ATF.BPTI was cloned in the EcoRV/HindIII digested adenoviral shuttle vector $\mathrm{pCMV}$.

In order to construct pCMV.BPTI the sequences encoding aminoacids 2 to 137 were deleted from $\mathrm{PCMV}$.ATF.BPTI using PCR with the oligonucleotides 5'TTCATTGCTGCCTTTGGTGTC3' and 5'CGACCTGACTTCTGCCTAGAG3'. After amplification the DNA fragment was recircularized resulting in a pCMV.BPTI.

To construct pCMV.ATF.BPTI.IRES.GFP, pBluescriptIRES.eGFP, encoding enhanced Green Fluorescent Protein downstream of an internal ribosome entry site (a kind gift from Dr. M. Heemskerk, Netherlands Cancer Institute, Amsterdam) was digested with NotI, blunted with PWO DNA polymerase, and subsequently digested with EcoRV. The blunt-ended IRES.GFP fragment was cloned into the EcoRV site in pCMV.ATF.BPTI.

For the generation of recombinant adenoviruses the pCMV constructs were co-transfected with pJM17 in HER 911 cells (25). Viral plaques were verified by PCR and restriction analysis. Viral stocks were prepared and frozen in aliquots with $15 \%(\mathrm{v} / \mathrm{v})$ glycerol at $-80^{\circ} \mathrm{C}$. Titers (expressed in plaque-forming units $/ \mathrm{ml}, \mathrm{pfu} / \mathrm{ml}$ ) were determined by plaque assay as described (25), and particle content was determined by OD260 measurement. All stocks used had comparable viral particle to pfu ratios.

\section{RNA Extraction and Northern Blot Analysis}

Total RNA was extracted from human saphenous vein SMC by the Chomczynski procedure (27). $5 \mu \mathrm{g}$ of total RNA was electrophoresed on a $1.2 \%$ (w/v) agarose-formaldehyde gel. The RNA integrity was confirmed by 
ethidium bromide staining. RNA was transferred to a nylon membrane filter (Amersham Phamacia Biotech, Almere, The Netherlands) and fixed by UV cross-linking. Filters were sequentially hybridized with [ $\left.{ }^{32} \mathrm{P}\right]$-labeled DNA probes for ATF or BPTI.

\section{Western Blotting}

Samples of conditioned CHO medium were subjected to SDS-PAGE and subsequently blotted onto nitrocellulose membrane as described previously (26). Recombinant proteins were visualized using rabbit anti-human u-PA polyclonal antibodies (28) and the ECL Chemiluminescence Western Blot kit (Amersham Pharmacia Biotech) according to the manufacturers protocol.

\section{ELISA}

To measure recombinant protein expression, ELISA's were set-up for ATF, BPTI, and ATF.BPTI. For the ATF ELISA, the monoclonal antibody UK2.1, recognizing the aminoterminal fragment of $\mathrm{u}-\mathrm{PA}$, was used as a catching antibody and a biotinylated rabbit polyclonal antibody directed against HMW u-PA was used as a detecting antibody (29). For the BPTI ELISA, a rabbit polyclonal antibody raised against aprotinin ( $\alpha$-Trasylol) was used both as a catching and as a detecting antibody. In the ATF.BPTI ELISA, UK2.1 was used as a catching antibody and biotinylated $\alpha$-Trasylol as a detecting antibody. Commercial standard u-PA (UKIDAN ${ }^{\circledR}$, Serono, Aubonne, Switzerland) and aprotinin (Trasylol ${ }^{\circledR}$, Bayer, Leverkusen, Germany) were used for reference values. To correct for possible variation in cell densities, the u-PA and aprotinin activities are expressed in $\mathrm{ng}$ and $\mathrm{mU}$, respectively, per $\mu \mathrm{g}$ protein as determined by the BCA protein assay (Pierce, Rockford, Illinois, USA). Since there is no standard for ATF.BPTI, values are given in OD 450. Endogenous u-PA production by the HSVSMC did not influence the ATF and ATF.BPTI measurements since recombinant protein production after infection was approximately 1000 -fold higher.

\section{Plasmin Activity Assay}

Recombinant protein activity was analyzed in a plasmin inhibition assay using the chromogenic substrate S2251 (Chromogenix, Mölndal, Sweden). Diluted samples of the conditioned HSVSMC medium were incubated for $15 \mathrm{~min}$ at room temperature with $200 \mathrm{pmol} / \mathrm{L}$ plasmin. S2251 was added and after $24 \mathrm{~h}$ incubation at $37^{\circ} \mathrm{C}$ the $\mathrm{A}_{405}$ was measured to determine the conversion of the chromogenic substrate. As a control, plasmin was incubated with buffer or with $1.0 \mathrm{KIU} / \mathrm{ml}$ aprotinin.

\section{Proliferation Assay}

Incorporation of $\left[{ }^{3} \mathrm{H}\right]$-thymidine in DNA was determined to measure cell proliferation. HSVSMC were seeded at $50 \%$ confluency in 24-well tissue culture plates and allowed to synchronise under serum-free conditions. After $24 \mathrm{~h}$ the medium was replaced by a concentration range of adenoviral dilutions and cells were infected for $24 \mathrm{~h}$ under serum free conditions. Cells were stimulated with DMEM supplemented with $10 \%$ (v/v) FCS $10 \%$ (v/v) human serum for $26 \mathrm{~h}$ at $37^{\circ} \mathrm{C}$ and labeled with $1 \mu \mathrm{Ci}$ of $\left[{ }^{3} \mathrm{H}\right]$-thymidine/well (Amersham Pharmacia Biotech) for the last $4 \mathrm{~h}$. Cells were then washed with ice-cold phosphate-buffered saline followed by ice-cold methanol and protein was subsequently precipitated with $5 \%(\mathrm{v} / \mathrm{v})$ trichloric acid and dissolved in $0.3 \mathrm{~mol} / \mathrm{L} \mathrm{NaOH}$. Tritiated thymidine incorporation was measured using a 1900CA Tri-CARB scintillation counter (Packard, Brussels, Belgium).

\section{Matrigel Invasion Assay}

Invasion of HSVSMC was assayed using a Transwell system with Matrigelcoated polycarbonate filters $(6.5 \mathrm{~mm}$ diameter, $8 \mu \mathrm{m}$ pore size; Costar, Cambridge, MA). Matrigel (Collaborative Biochemical Products, Bedford, MA) was layered onto the filter $(14 \mu \mathrm{g} / \mathrm{well})$ and allowed to dry at room temperature. The membrane was hydrated with DMEM before use. Cultured HSVSMC

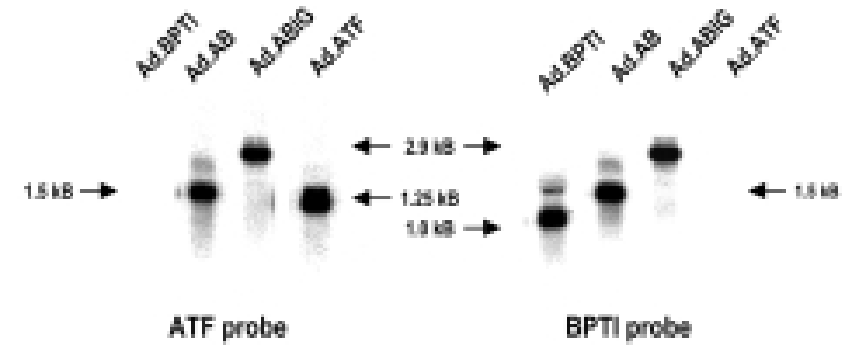

Fig. 2 Northern blot analysis of Ad.BPTI, Ad.ATF.BPTI, Ad.ABIG, and Ad.ATF infected SMC. Total cellular RNA was harvested from human saphenous vein SMC that were infected overnight with Ad.BPTI, Ad.ATF.BPTI, Ad.ABIG, or Ad.ATF. mRNA was analyzed on Northern blots probed for ATF or BPTI

$\left(4 \times 10^{4}\right.$ cells in $175 \mu \mathrm{l}$ DMEM) were seeded in the upper chamber, and $900 \mu \mathrm{l}$ DMEM was put in the lower compartment. Cells were allowed to attach to the membrane for $4 \mathrm{~h}$ before a concentration range of $25 \mu \mathrm{l}$ adenovirus, or $25 \mu \mathrm{ldi}$ luted virus storage buffer as a control, were added to the upper compartments. After $16 \mathrm{~h}$ the medium of the upper chamber was replaced by $200 \mu \mathrm{l}$ DMEM supplemented with $0.15 \mu \mathrm{mol} / \mathrm{L}$ plasminogen, and $900 \mu \mathrm{l}$ DMEM supplemented with $0.15 \mu \mathrm{mol} / \mathrm{L}$ plasminogen and $10 \%$ FCS as chemoattractant replaced the medium in the lower chamber. As a control aprotinin $(10-100 \mathrm{KIU} / \mathrm{ml})$, was added to both upper and lower chambers. After 4 days of incubation at $37^{\circ} \mathrm{C}$ in $5 \% \mathrm{CO}_{2} / 95 \%$ air $(\mathrm{v} / \mathrm{v})$ the cells were fixed with $2.5 \%(\mathrm{v} / \mathrm{v})$ glutaraldehyde. Matrigel and cells on the upper side of the filter were scraped off with a cotton swab, and cells on the lower side of the filter were stained with $2 \mathrm{~g} / \mathrm{L}$ crystal violet solution. Invasion was determined by the $\%$ surface area covered by cells as measured by image analysis using an Olympus CK2 inverted microscope equipped with a monochrome CCD camera (MX5). Data were analyzed using Optimas image analysis software (BioScan Inc., WA, USA).

\section{Analysis of Green Fluorescent Protein Expression}

Ad.ABIG infected HSVSMC were lysed in 0.5\% (v/v) TritonX-100, $30 \mathrm{~min}$ at $4^{\circ} \mathrm{C}$. Fluorescence by infected cells was measured using a Cytofluor II (Perseptive Biosystems, MA, USA) with excitation at $485 \mathrm{~nm}$ and emission at $530 \mathrm{~nm}$.

Detection of GFP expression in HSVSMC on Transwell filter membranes was achieved by carefully detaching the filter membranes from the inserts. After incubation in $6.8 \%(\mathrm{w} / \mathrm{v})$ sucrose in PBS (15 min), the filters were embedded in OTC compound (Sakura, Zoeterwoude, The Netherlands). Frozen section were cut at 5 ( $\mathrm{m}$ and expression of GFP was monitored by fluorescence microscopy using a Nikon Microphot-FXA microscope with a FITC-filter Omega XF100.

\section{Statistical Analysis}

Data are presented as mean \pm SEM. Statistical analysis was performed with one way analysis of variance (ANOVA) followed by Fisher's Least Significant Difference test. Statistical significance was accepted for $\mathrm{p}<0.05$.

\section{Results}

Characterization of Recombinant ATF, BPTI, ATF.BPTI, and ABIG

HSVSMC infected overnight with $10^{8} \mathrm{pfu} / \mathrm{ml}$ of Ad.ATF, Ad.BPTI, Ad.ATF.BPTI, or Ad.ABIG were subjected to Northern blot analysis in order to examine the mRNA expression of the various transgenes (Fig. 2). The filter was sequentially hybridized with an ATF probe and a BPTI probe and the presence and correct size of the two corresponding 

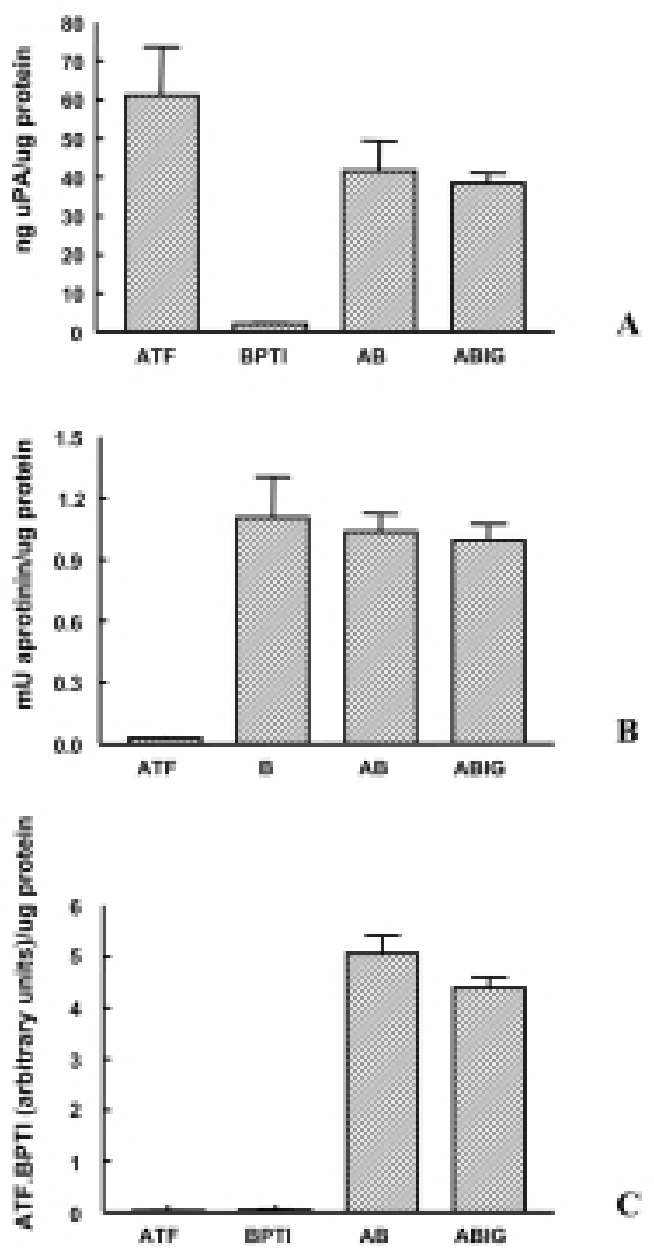

Fig. 3 Quantitative comparison of recombinant protein production. Conditioned medium of human saphenous vein SMC infected with Ad.ATF, Ad.BPTI, Ad.ATF.BPTI, and Ad.ABIG was tested in the ATF ELISA (A), Aprotinin ELISA (B), and the specific ATF.BPTI ELISA (C)

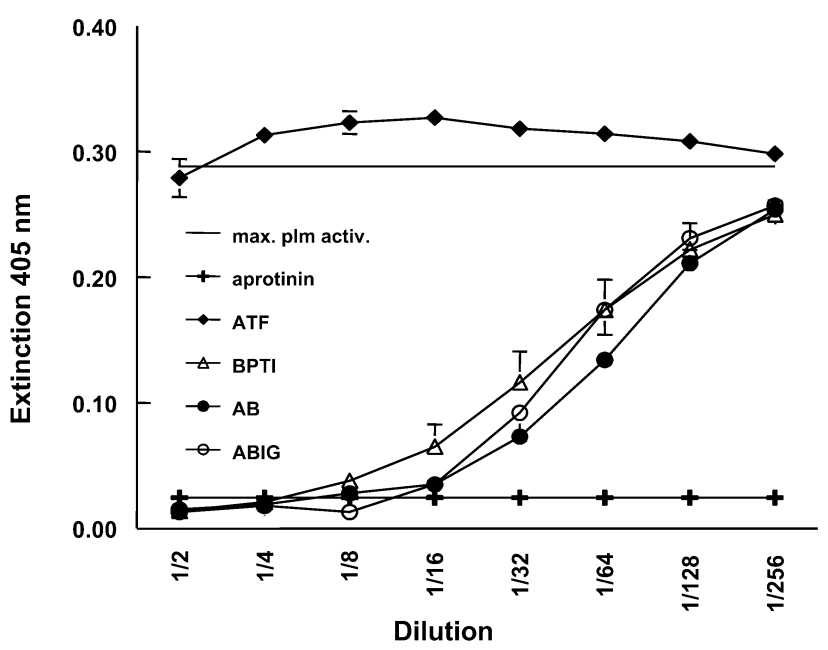

Fig. 4 Plasmin inhibition assay. Diluted samples of conditioned medium from human saphenous vein SMC infected with Ad.ATF, Ad.BPTI, Ad.ATF.BPTI, and Ad.ABIG were analyzed for plasmin inhibitory activity at the indicated dilution. Maximal plasmin activity was established by addition of $200 \mathrm{pmol} / \mathrm{L}$ plasmin. Complete inhibition of plasmin activity was established by addition of $1 \mathrm{KIU} / \mathrm{ml}$ aprotinin
mRNAs was confirmed ( $1.25 \mathrm{kB}$ and $1.0 \mathrm{kB}$ respectively). Both probes also hybridized with a $1.5 \mathrm{kB}$ band and a $2.9 \mathrm{kB}$ band corresponding to ATF.BPTI mRNA and ABIG mRNA, respectively.

The production of ATF.BPTI protein was visualized by Western blotting (not shown). Analysis was performed on conditioned medium from $\mathrm{CHO}$ cells infected with $10^{8} \mathrm{pfu} / \mathrm{ml}$ of the various adenoviral vectors. Using an antibody against human u-PA to detect the ATF domain, the presence and correct size of ATF $(15 \mathrm{kDa})$ and ATF.BPTI $(26 \mathrm{kDa})$ were confirmed. The same sized protein $(26 \mathrm{kDa})$ was produced by ATF.BPTI and ABIG, although the mRNA's from the two constructs differ in size. This is due to the Internal Ribosome Entry Site (IRES) in the ABIG construct, which results in a separate translation of the ATF.BPTI and GFP proteins.

The secretion of the recombinant proteins into the conditioned medium of HSVSMC was quantified by ELISAs for ATF, BPTI and the ATF-BPTI hybrid. The latter assay used anti-u-PA IgG as a catching antibody and anti-BPTI IgG as a tagging antibody. All three recombinant proteins increased dose-dependently with increasing adenovirus concentrations (not shown). In the ATF ELISA (Fig. 3a) a comparable production of ATF.BPTI was found in the cells transfected with $10^{8}$ pfu/ml Ad.ATF.BPTI and Ad.ABIG $(41.5 \pm 7.9$ and $38.4 \pm 2.5 \mu \mathrm{g} \mathrm{u}-$ $\mathrm{PA} / \mu \mathrm{g}$ protein respectively) while ATF appears to be produced more efficiently (49.5 $\pm 6.6 \mu \mathrm{g} \mathrm{u}-\mathrm{PA} / \mu \mathrm{g}$ protein). This discrepancy in transgene production was in agreement with mRNA levels as observed by Northern blot analysis (Fig. 2). In the BPTI ELISA (Fig. 3b), SMC infected with $10^{8} \mathrm{pfu} / \mathrm{ml}$ Ad.BPTI, Ad.ATF.BPTI, and Ad.ABIG, gave comparable antigen levels $(1.10 \pm 0.20,1.04 \pm 0.09$, and $0.99 \pm 0.08$ $\mathrm{mKIU}$ aprotinin $/ \mu \mathrm{g}$ protein respectively). In the ATF.BPTI specific ELISA only Ad.ATF.BPTI and Ad.ABIG infected SMC ( $\left.10^{8} \mathrm{pfu} / \mathrm{ml}\right)$ gave a strong and comparable signal (Fig. 3c).

\section{Inhibition of Plasmin Activity}

Plasmin inhibitory activity was measured to assess the functionality of the secreted recombinant proteins. In a plasmin inhibition assay, diluted samples of conditioned medium from HSVSMC infected with the various adenoviral vectors were analyzed. Whereas ATF had no inhibitory effect on plasmin activity, ATF.BPTI, ABIG, and BPTI were capable of inhibiting $200 \mathrm{pmol} / \mathrm{L}$ plasmin by more than $90 \%$ up to $1: 8$ dilution, this is comparable to the effect of $1 \mathrm{KIU} / \mathrm{ml}$ of aprotinin (Fig. 4). A significant inhibition of plasmin activity was observed up to a dilution of $1: 256$.

To demonstrate that ATF.BPTI is able to inhibit plasmin activity at the cell surface, mouse LB6 cells expressing human u-PAR, as well as control LB-6 cells, were incubated for $1 \mathrm{~h}$ with ATF.BPTI-containing $\mathrm{CHO}$ medium. After extensive washing cell extracts were prepared and the plasmin inhibitory capacity was determined as described in "materials and methods". Plasmin inhibition $(93.2 \pm 2.1 \%)$ could only be detected in extracts of u-PAR expressing cells but not in the control LB6 cells (Table 1). Inhibition of plasmin activity at the surface of HSVSMC was achieved in a similar way. Incubating HSVSMC with the ATF.BPTI-containing $\mathrm{CHO}$ cell culture medium resulted in a plasmin activity inhibition of $85.2 \pm 3.9 \%$. Binding of u-PA to its receptor u-PAR is reversible and receptor-bound u-PA can be removed by a mild acid treatment. This feature was used to further demonstrate that functional ATF.BPTI was bound to the u-PAR on the cells. After incubation of the cells with ATF.BPTI medium and extensive washing, part of 
the cells underwent a mild acid treatment ( 2 min incubation with $\mathrm{pH} 3.0$ glycine buffer) before cell lysates were prepared. No plasmin inhibitory activity could be detected in the lysates of the acid treated cells. After incubation of SMC with BPTI-containing CHO conditioned medium, no plasmin inhibiting activity before or after the acid treatment could be detected in cell lysates. These results indicate that ATF successfully anchors BPTI to the u-PAR where it can inhibit plasmin activity at the cell-surface.

\section{Efficiency of Adenoviral Transfection of HSVSMC}

To determine the adenovirus concentration for maximal transfection, $4 * 10^{4}$ HSVSMC were seeded onto 48 -well plates and infected with a concentration range of Ad.ABIG for $16 \mathrm{~h}$. Expression of ABIG was determined by measuring relative fluorescence by GFP in cell extracts and ATF.BPTI antigen levels in the conditioned medium after 5 days. ATF.BPTI antigen levels, as measured by ATF ELISA, were above detection limit starting at $5^{*} 10^{5} \mathrm{pfu} / \mathrm{ml}$. A dose dependent increase in antigen levels was found up to a maximum of $200 \mu \mathrm{g} / \mathrm{ml}$ at a vector concentration of $5^{*} 10^{8}$ to $1^{*} 10^{9} \mathrm{pfu} / \mathrm{ml}$. Fluorescence, however, did not exceed the detection limit up to $5^{*} 10^{6} \mathrm{pfu} / \mathrm{ml}$ but also reached a maximum at $5^{*} 10^{8}$ to $1^{*} 10^{9} \mathrm{pfu} / \mathrm{ml}$ (Fig. 5). This also shows that ATF.BPTI linked to GFP with an IRES sequence results in the expression of ATF.BPTI and GFP in a proportional relationship at Ad.ABIG concentrations of $5 * 10^{6} \mathrm{pfu} / \mathrm{ml}$ or higher. Infection with vector concentrations above $10^{9}$ resulted in cytotoxic effects as shown by a decrease in relative fluorescence, a decrease in ATF.BPTI production and by changes in cell morphology (not shown). To be certain that no cytotoxic effects would occur, a maximum adenovirus concentration of $1 * 10^{8} \mathrm{pfu} / \mathrm{ml}$ was chosen for further experiments.

\section{Effect of ATF and ATF.BPTI Expression on HSVSMC Proliferation}

The possible mitogenic effect in response to increasing concentrations of ATF on HSVSMC was determined by measuring $\left[{ }^{3} \mathrm{H}\right]$ thymidine incorporation of Ad.ATF infected cells in comparison to Ad.BPTI, AdATF.BPTI, and control vector infected cells (Fig. 6). Although $\left[{ }^{3} \mathrm{H}\right]$ thymidine incorporation was slightly decreased by adenoviral infection per se, no significant differences in incorporation were detected among the various adenoviral constructs. This indicates that under the conditions used in our experiments, overexpression of ATF or ATF.BPTI has no effect on HSVSMC proliferation.

\section{Monitoring of Ad.ABIG Infected HSVSMC}

Infection with Ad.ABIG gives insight into the behavior of the infected cells due to the visibility of the GFP. As shown in Fig. 7a, infection with $10^{7} \mathrm{pfu} / \mathrm{ml}$ gave rise to a significant number of GFP-expressing HSVSMC on the Transwell filter. Cleaning of the upper compartment 4 days after stimulation removed virtually all GFP expression (Fig. 7b), whereas the presence of migrated cells on the bottom-side of the filter could be detected by staining with christal violet solution (Fig. 7c). This indicates that the migrated SMC were derived from the cell population that did not express GFP, and consequently no ATF.BPTI. A crosssec-
Table 1 Inhibition of plasmin activity at the cell-surface

\begin{tabular}{l|cc}
\hline & Before acid treatment & After acid treatment \\
\hline & inhibition plasmin activity by ATF.BPTI \\
Control LB 6 & $0 \%$ & $0 \%$ \\
UPAR LB6 & $93.2 \pm 2.1 \%$ & $0 \%$ \\
HSVSMC & $85.2 \pm 3.9 \%$ & $0 \%$ \\
\hline & Inhibition plasmin activity by BPTI \\
HSVSMC & $0 \%$ & $0 \%$ \\
\hline
\end{tabular}

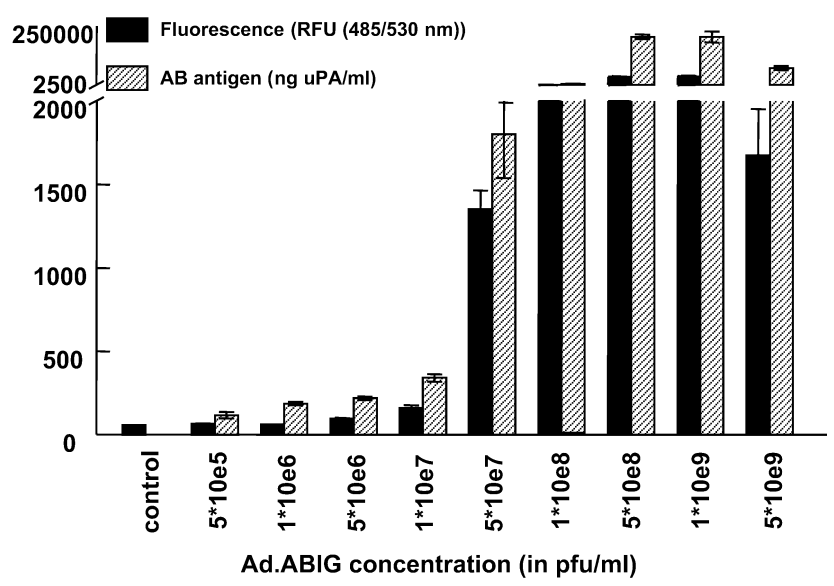

Fig. 5 Comparison of GFP and ATF.BPTI expression in Ad.ABIG infected human saphenous vein SMC. GFP expression was measured by relative fluorescence of cell extracts and ATF.BPTI expression was measured by ATF ELISA of corresponding conditioned media of SMC infected with a concentration range of Ad.ABIG. Fluorescence is given in relative fluorescence units (RFU) and ATF.BPTI antigen is given in $\mathrm{ng} \mathrm{uPA} / \mathrm{ml}$

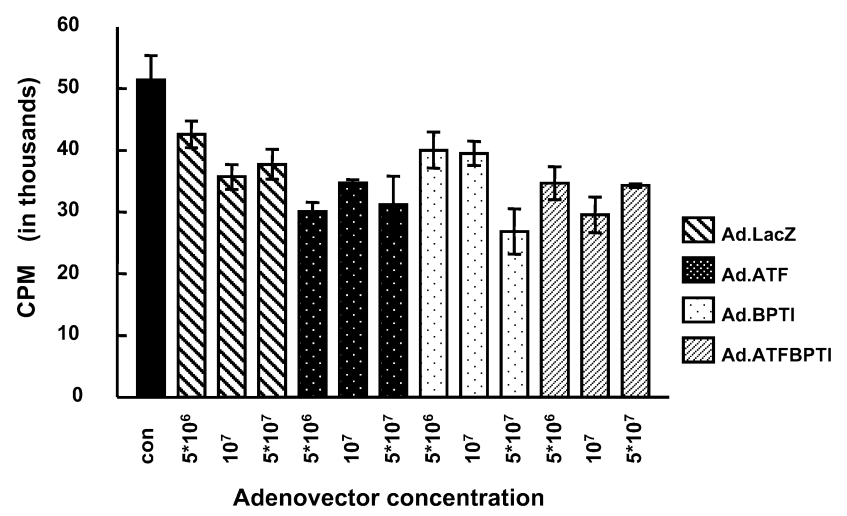

Fig. 6 Proliferation assay. The proliferation of human human saphenous vein SMC infected with Ad.ATF, Ad.BPTI, Ad.ATF.BPTI, and Ad.LacZ as a control vector was determined by measuring $[3 \mathrm{H}]$ thymidine incorporation. As an additional control the proliferation of non-infected SMC was measured (con). Results are expressed in counts per min $(\mathrm{cpm}) \pm$ SEM 
Fig. 7 Visualization of GFP expression. SMC were placed on Matrigel coated filters and infected with Ad.ABIG. Four days after infection migration of SMC was analyzed by en face fluorescence microscopy, showing GFP-producing cells (A). After removing cells from upper compartment, GFP-expressing cells that had migrated through the filter were photographed (B). Christal Violet staining shows the presence of migrated cells on bottom of filter (C). A crosssection before cleaning of upper compartment shows GFP-producing cells only on upper side of filter (D)
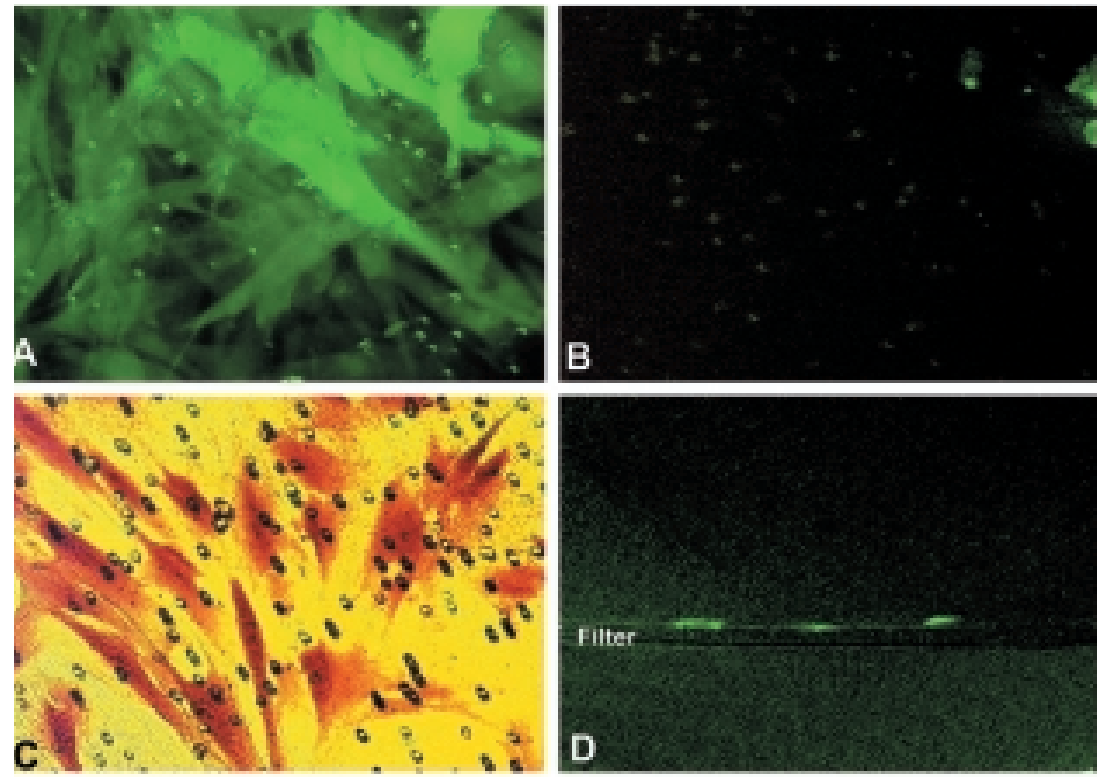

tion of a Transwell filter 4 days after infection, also shows fluorescent cells only on the upper side and not on the bottom of the filter (Fig. 7d).

\section{Effect of ATF and ATF.BPTI Expression on HSVSMC Migration}

HSVSMC migration is dependent on degradation of the extracellular matrix by cellular proteases. Therefore, we studied the effects of inhibiting plasmin activation and/or activity by adenoviral infection of HSVSMC with Ad.ATF, Ad.BPTI, and Ad.ATF.BPTI, and Ad.LacZ as a control, on cell migration in a Transwell filter assay. As can be seen in Fig. 8, HSVSMC are able to migrate across the Matrigel coated porous filter under control conditions. Addition of aprotinin reduces migration by $52 \%$ at a concentration of $100 \mathrm{KIU} / \mathrm{ml}$. All adenoviral

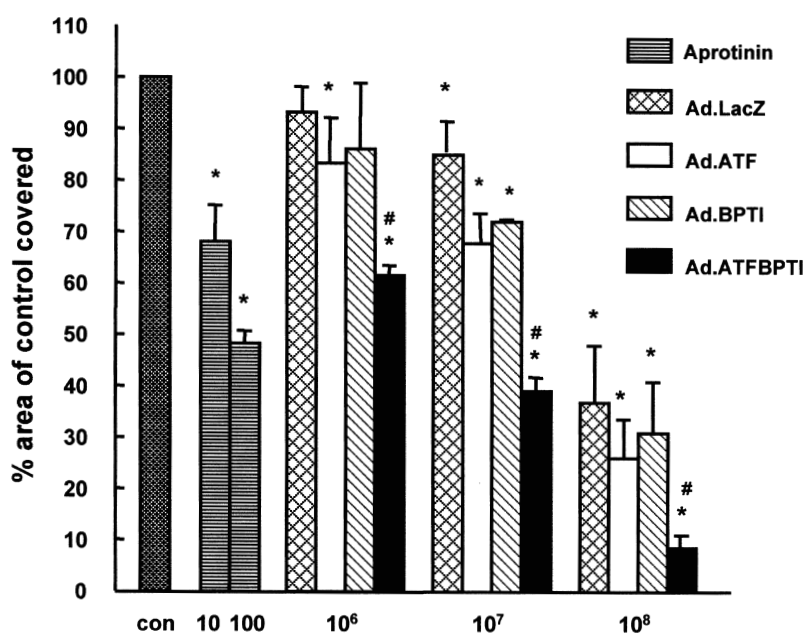

Fig. 8 Migration assay. The migration of human human saphenous vein SMC infected with Ad.ATF, Ad.BPTI, Ad.ATF.BPTI, and Ad.LacZ as a control vector was determined by quantification of the number of cells that migrated through the Matrigel-coated Transwell filter. Adenovector concentrations are given in $\mathrm{pfu} / \mathrm{ml}$ and aprotinin concentrations in $\mathrm{KIU} / \mathrm{ml}$. The results are presented as percentage of control \pm SEM. $* \mathrm{P}<0.05$ compared to control (no virus), \# $\mathrm{P}<0.05$ compared to the corresponding Ad.LacZ virus concentration vectors show a dose-dependent reduction of SMC migration. Infection with control virus Ad.LacZ, results in a significant reduction of cell migration at concentrations of $10^{7} \mathrm{pfu} / \mathrm{ml}$ and higher. Both Ad.ATF and Ad.BPTI inhibit migration slightly more than Ad.LacZ, maximally $74 \%$ and $69 \%$, respectively, at $10^{8} \mathrm{pfu} / \mathrm{ml}$. Infection with Ad.ATF.BPTI was shown to be the most effective. At the lowest adenovirus concentration of $10^{6} \mathrm{pfu} / \mathrm{ml}$ migration is already significantly inhibited by $48 \%$, increasing to $91 \%$ at $10^{8} \mathrm{pfu} / \mathrm{ml}$. Contrary to Ad.ATF and Ad.BPTI, Ad.ATF.BPTI was also significant at all concentrations when compared to the corresponding Ad.LacZ-infected controls.

\section{Discussion}

Pharmacological approaches to the prevention of restenosis in man have so far shown little or no effect or provide conflicting data $(30,31)$. Therefore, research has been directed to the development of novel strategies, such as gene therapy, with the expectation that local release of inhibitors will be more beneficial. Here we report a gene therapeutic approach aimed to reduce SMC migration by inhibition of pericellular plasmin activity. A novel adenoviral construct was devised, encoding the hybrid protein ATF.BPTI, which contains the active domain of bovine pancreas trypsin inhibitor (BPTI), a potent inhibitor of plasmin, and ATF, the receptor binding domain of u-PA, in order to target BPTI to the cell-surface $\mathrm{u}-\mathrm{PA}$ receptor. The effects of infection of SMC with Ad.ATF.BPTI on plasmin inhibition and cell migration were compared with adenoviral constructs encoding BPTI and ATF alone. To identify the ATF.BPTI expressing cells, an adenoviral vector was constructed to express ATF.BPTI and Green Fluorescent Protein (GFP) simultaneously (Ad.ABIG).

The ATF.BPTI construct combines features of both the ATF domain of u-PA and the plasmin inhibitor BPTI. Previous in vitro studies have shown that migration of SMC is reduced by inhibition of plasmin or $\mathrm{u}$ PA activity, and by interfering with the binding of u-PA to its receptor 6-8). The hybrid construct combines these activities by localizing plasmin inhibition to the cell surface via the u-PA receptor. This causes several effects. First, effective plasmin inhibition is realized on the cell surface, prohibiting plasmin to degrade cell-matrix contacts, matrix components, and to activate MMPs (32). Secondly, the construct prevents u-PA from binding to its receptor by competition. Finally, the 
ATF.BPTI hybrid interacts with the u-PA receptor, which may cause signal transduction by the occupied u-PA receptor.

Our data show that infection of HSVSMC with ATF.BPTI, resulted in a strong inhibition of SMC migration, up to $91 \%$ of control, whereas gene transfer of BPTI, the non-receptor binding plasmin inhibitor, reduced the migratory ability of HSVSMC up to $69 \%$. This implies that localization of a plasmin inhibitor to the cell surface makes a more potent inhibitor of cell migration than plasmin inhibition in the extracellular environment, as when BPTI is secreted by the cell and not associated to the cell-surface. Indeed, addition of high concentrations of exogenous aprotinin $(100 \mathrm{KIU} / \mathrm{ml})$ was comparable to Ad.BPTI by inhibiting cell migration up to $52 \%$.

In the ATF.BPTI construct the BPTI domain is bound to the carboxyterminal part of ATF, leaving the growth factor domain of u-PA unoccupied. Because ATF and urokinase bind with similar affinities to the u-PA receptor (33), it is likely that ATF.BPTI also binds with a similar affinity. Therefore, ATF.BPTI is expected to inhibit u-PA binding to its receptor to a similar extent as ATF does. This inhibition can reduce cell migration directly by preventing the generation of urokinase and subsequently plasmin activity on the cell surface (34). On the contrary, various studies have claimed that occupancy of u-PAR by uPA also promotes cell migration by initiating intracellular signaling events . Addition of ATF has been reported to increase melanoma metastasis and bovine endothelial cell migration in vitro (37). However, in our experiments Ad.ATF infected HSVSMC were partially inhibited in their migratory ability. This agrees with the proposed competitive inhibition of ATF with u-PA for the u-PAR. These results are further supported by a study described by Li et al. (38) where adenoviral delivery of ATF to various tumor types in murine models led to inhibition of metastasis. Furthermore, addition of soluble u-PA receptor or a receptorblocking antibody to an in vitro angiogenesis model was shown to prevent migration and subsequent tube-formation by endothelial cells in a fibrin matrix (39).

Intracellular signaling mediated via the u-PAR has also been implicated in cell proliferation. In vitro studies have described the mitogenic effects of HMWu-PA and ATF in various cell types (17, 40, 41). To assess if effects on proliferation may have influenced the results obtained in the invasion assay, thymidine incorporation was assayed. Thymidine incorporation by Ad.ATF infected HSVSMC, however, did not significantly differ from Ad.BPTI, Ad.ATF.BPTI, or control adenovector infected HSVSMC. These results may be explained by a study from Kanse et al. (16), which describes the mitogenic effects of u-PA but not ATF on SMC and suggests a u-PA receptor independent mechanism for induction of proliferation. In addition, we have shown that proteolytically inactive $\mathrm{u}-\mathrm{PA}$ is able to induce a mitogenic response in quiescent melanoma cells by a mechanism that involves the ATF domain but is independent of high affinity binding to u-PAR. It was also found that $\mathrm{u}-$ $\mathrm{PA}$ is able to bind to an unidentified membrane associated protein that could be involved in u-PA-induced signal transduction in melanoma cells (41). Therefore, differences in mitogenic effects that have been reported are most likely related to differences in cell type and concentrations of u-PA and ATF in the various models. It can be concluded that the inhibition of SMC migration by ATF.BPTI is not caused by an inhibition of proliferation or signaling, but appears completely due to inhibition of local plasmin activity.

Anti-migratory gene transfer in vascular smooth muscle cells has also been approached by local overexpression of natural inhibitors of the matrix metalloproteinases, TIMP-1, TIMP-2 and TIMP-3 (42, 43). Because plasmin can activate directly or indirectly several MMPs, it is possible that plasmin inhibition also contributes by a reduction of MMP activation. Future studies comparing the effects of ATF.BPTI with various TIMPs and in combination with them are needed to clarify this aspect.

Our study also demonstrated that ATF.BPTI linked to GFP with an IRES sequence results in the expression of ATF.BPTI and GFP in a proportional relationship, such that the magnitude of expression of GFP reflects the magnitude of expression of ATF.BPTI, at Ad.ABIG concentrations of $5^{*} 10^{6} \mathrm{pfu} / \mathrm{ml}$ or higher. The bicistronic co-expression of a therapeutic and an autofluorescent marker gene provides us with a tool to monitor gene transfer and the subsequent behavior of the transfected cells.

In conclusion, our results show that local expression of the novel hybrid protein, ATF.BPTI leads to profound inhibition of SMC migration. ATF.BPTI is more potent than ATF or BPTI individually, indicating that targeting BPTI action to the cell surface leads to a substantial increase in effectivity. Local expression of this hybrid protein by adenoviral gene transfer presents a promising approach in the prevention of intimal SMC migration and consequently restenosis.

\section{Acknowledgements}

This study is supported by the Netherlands Heart foundation, grants 95-126 and M93-001.

\section{Addendum}

Each of the authors contributed to this study as follows: Lamfers and Aalders performed most of the experiments, Wijnberg and Huisman have set up and validated the SMC invasion experiments, Grimbergen and Cohen performed the construction and validation of the adenoviral vectors, Verheijen, van Hinsbergh and Quax designed the adenoviral constructs for the hybrid protein and derivatives, and designed and supervised the study.

\section{References}

1. Plow EF, Freaney DE, Plescia J, Miles LA. The plasminogen system and cell surfaces: evidence for plasminogen and urokinase receptors on the same cell type. J Cell Biol 1986; 103: 2411-20.

2. Reuning U, Magdolen V, Wilhelm O, Fischer K, Lutz V, Graeff H, Schmitt M. Multifunctional potential of the plasminogen activation system in tumor invasion and metastasis. Int J Oncol 1998; 13: 893-906.

3. Blasi F. The urokinase receptor and cell migration. Semin Thromb Hemost 1996; 22: 513-6.

4. Pepper MS, Montesano R, Mandriota SJ, Orci L, Vassalli JD. Angiogenesis: a paradigm for balanced extracellular proteolysis during cell migration and morphogenesis. Enzyme Protein 1996; 49: 138-62.

5. Tkachuk V, Stepanova V, Little PJ, Bobik A. Regulation and role of urokinase plasminogen activator in vascular remodelling. Clin Exp Pharmacol Physiol 1996; 23: 759-65.

6. Wijnberg MJ, Quax PHA, Nieuwenbroek NM, Verheijen JH. The migration of human smooth muscle cells in vitro is mediated by plasminogen activation and can be inhibited by alpha2-macroglobulin receptor associated protein. Thromb Haemost 1997; 78: 880-6.

7. Okada SS, Grobmyer SR, Barnathan ES. Contrasting effects of plasminogen activators, urokinase receptor, and LDL receptor-related protein on smooth muscle cell migration and invasion. Arterioscler Thromb Vasc Biol 1996; 16: 1269-76.

8. Herbert JM, Lamarche I, Carmeliet P. Urokinase and tissue-type plasminogen activator are required for the mitogenic and chemotactic effects of bovine fibroblast growth factor and platelet-derived growth factor-BB for vascular smooth muscle cells. J Biol Chem 1997; 272: 23585-91. 
9. Jackson CL, Reidy MA. The role of plasminogen activation in smooth muscle cell migration after arterial injury. Ann N Y Acad Sci 1992; 667: 141-50.

10. Reidy MA, Irvin C, Lindner V. Migration of arterial wall cells. Expression of plasminogen activators and inhibitors in injured rat arteries. Circ Res 1996; 78: 405-14.

11. Carmeliet P, Moons L, Ploplis V, Plow E, Collen D. Impaired arterial neointima formation in mice with disruption of the plasminogen gene. J Clin Inves 1997; 99: 200-8.

12. Carmeliet P, Moons L, Herbert JM, Crawley J, Lupu F, Lijnen R, Collen D. Urokinase but not tissue plasminogen activator mediates arterial neointima formation in mice. Circ Res 1997; 81: 829-39.

13. Appella E, Blasi $F$. The growth factor module of urokinase is the binding sequence for its receptor. Ann N Y Acad Sci 1987; 511:192-5.

14. Appella E, Robinson EA, Ullrich SJ, Stoppelli MP, Corti A, Cassani G, Blasi F. The receptor-binding sequence of urokinase. A biological function for the growth-factor module of proteases. J Biol Chem 1987; 262: 4437-40.

15. Behrendt N, Ronne E, Ploug M, Petri T, Lober D, Nielsen LS, Schleuning WD, Blasi F, Appella E, Dano K. The human receptor for urokinase plasminogen activator. NH2-terminal amino acid sequence and glycosylation variants. J Biol Chem 1990; 265: 6453-60.

16. Kanse SM, Benzakour O, Kanthou C, Kost C, Lijnen HR, Preissner KT. Induction of vascular SMC proliferation by urokinase indicates a novel mechanism of action in vasoproliferative disorders. Arterioscler Thromb Vasc Biol 1997; 17: 2848-54.

17. Rabbani SA, Gladu J, Mazar AP, Henkin J, Goltzman D. Induction in human osteoblastic cells (SaOS2) of the early response genes fos, jun, and myc by the amino terminal fragment (ATF) of urokinase. J Cell Physiol 1997; 172: 137-45.

18. Kirchheimer JC, Christ G, Binder BR. Growth stimulation of human epidermal cells by urokinase is restricted to the intact active enzyme. Eur $\mathrm{J}$ Biochem 1989; 181: 103-7.

19. Hall SW, Humphries JE, Gonias SL. Inhibition of cell surface receptorbound plasmin by alpha 2-antiplasmin and alpha 2-macroglobulin. J Biol Chem 1991; 266: 12329-36.

20. Reuning U, Dixon EP, Little SP, Bang NU. Mitogen crosstalk accompanying urokinase receptor expression in stimulated vascular smooth muscle cells. FEBS Letters 1996; 392: 125-8.

21. Quax PHA, Lamfers MLM, Grimbergen JM, Verheijen JH, Vanhinsbergh VWM. Inhibition of neointima formation in cultured human saphenous vein segments by an adenovirus expressing a urokinase receptor-binding plasmin inhibitor. Circulation 1997; 96: I-669 (Abstract).

22. Gerdes HH, Kaether C. Green fluorescent protein: applications in cell biology. FEBS Lett 1996; 389: 44-7.

23. Chalfie M, Tu Y, Euskirchen G, Ward WW, Prasher DC. Green fluorescent protein as a marker for gene expression. Science 1994; 263: 802-5.

24. Kocan RM, Moss NS, Benditt EP. Human arterial wall cells and tissues in culture. Methods Cell Biol 1980; 21A:153-66.

25. Fallaux FJ, Kranenburg O, Cramer SJ, Houweling A, van Ormondt H, Hoeben RC, van der Eb AJ. Characterization of 911: a new helper cell line for the titration and propagation of early region 1-deleted adenoviral vectors. Hum Gene Ther 1996; 7: 215-22.

26. Quax PHA, Grimbergen JM, Lansink M, Bakker AHF, Blatter MC, Belin D, Vanhinsbergh VWM, Verheijen JH. Binding of human urokinase-type plasminogen activator to its receptor - residues involved in species specificity and binding. Arterioscler Thromb Vasc Biol 1998; 18: 693-701.

27. Chomczynski P, Sacchi N. Single-step method of RNA isolation by acid guanidinium thiocyanate- phenol-chloroform extraction. Anal Biochem 1987; 162: 156-9.
28. Binnema DJ, van Iersel JJ, Dooijewaard G. Quantitation of urokinase antigen in plasma and culture media by use of an ELISA. Thromb Res 1986; 43: 569-77.

29. Vanboheemen P, Vandenhoogen C, Koolwijk P. Comparison of the inhibition of urokinase-type plasminogen activator (u-PA) activity by monoclonal antibodies specific for u-PA as assessed by different assays. Fibrinolysis 1995; 9: 343-9.

30. Lefkovits J, Topol EJ. Pharmacological approaches for the prevention of restenosis after percutaneous coronary intervention. Prog Cardiovasc Dis 1997; 40: 141-58

31. Herrman JP, Hermans WR, Vos J, Serruys PW. Pharmacological approaches to the prevention of restenosis following angioplasty. The search for the Holy Grail? (Part II). Drugs 1993; 46: 249-62.

32. Mignatti P. Extracellular matrix remodeling by metalloproteinases and plasminogen activators. Kidney Int 1995; 49:S12-4.

33. Nielsen LS, Kellerman GM, Behrendt N, Picone R, Dano K, Blasi F. A 55,000-60,000 Mr receptor protein for urokinase-type plasminogen activator. Identification in human tumor cell lines and partial purification. J Biol Chem 1988; 263: 2358-63.

34. Ellis V, Behrendt N, Dano K. Plasminogen activation by receptor-bound urokinase. A kinetic study with both cell-associated and isolated receptor. J Biol Chem 1991; 266: 12752-8.

35. Stepanova V, Bobik A, Bibilashvily R, Belogurov A, Rybalkin I, Domogatsky S, Little PJ, Goncharova E, Tkachuk V. Urokinase plasminogen activator induces smooth muscle cell migration: key role of growth factorlike domain. FEBS Lett 1997; 414: 471-4.

36. Fazioli F, Resnati M, Sidenius N, Higashimoto Y, Appella E, Blasi F. A urokinase-sensitive region of the human urokinase receptor is responsible for its chemotactic activity. EMBO J 1997; 16: 7279-86.

37. Stahl A, Mueller BM. Melanoma cell migration on vitronectin: regulation by components of the plasminogen activation system. Int J Cancer 1997; 71: 116-22.

38. Li H, Lu H, Griscelli F, Opolon P, Sun LQ, Ragot T, Legrand Y, Belin D, Soria J, Soria C, Perricaudet M, Yeh P. Adenovirus-mediated delivery of a uPA/uPAR antagonist suppresses angiogenesis-dependent tumor growth and dissemination in mice. Gene Therapy 1998; 5: 1105-13.

39. Kroon ME, Koolwijk P, van Goor H, Weidle UH, Collen A, van der Pluijm G, van Hinsbergh VWM. Role and localization of urokinase receptor in the formation of new microvascular structures in fibrin matrices. Am J Pathol 1999; 154: 1731-42.

40. De Petro G, Copeta A, Barlati S. Urokinase-type and tissue-type plasminogen activators as growth factors of human fibroblasts. Exp Cell Res 1994; 213: $286-94$

41. Koopman JL, Slomp J, de Bart AC, Quax PH, Verheijen JH. Mitogenic effects of urokinase on melanoma cells are independent of high affinity binding to the urokinase receptor. J Biol Chem 1998; 273: 33267-72.

42. Baker AH, Zaltsman AB, George SJ, Newby AC. Divergent effects of tissue inhibitor of metalloproteinase- $1,-2$, or -3 overexpression on rat vascular smooth muscle cell invasion, proliferation, and death in vitro - TIMP-3 promotes apoptosis. J Clin Invest 1998; 101: 1478-87.

43. Baker AH, George SJ, Zaltsman AB, Murphy G, Newby AC. Inhibition of invasion and induction of apoptotic cell death of cancer cell lines by overexpression of TIMP-3. Br J Cancer 1999; 79: 1347-55.

Received December 17, 1999 Accepted after revision February 21, 2000 